\title{
Community Resilience and Placemaking through Translocal Networking: Learning from Thailand and the Philippines
}

\author{
Astrid Ley \\ University of Stuttgart, International Urbanism, Germany \\ astrid.ley@si.uni-stuttgart.de
}

\begin{abstract}
Research on community resilience has historically focused strongly on the local features of communities which in support of and display resilient behaviour in times of stress and in the face of a range of shocks. However, the argument presented in this paper is that both prior organisation - often within the realm of public space belonging to a community - and connectivity beyond the locality which reaches the international level, need to be taken into consideration as significant aspects of community resilience. Last but not least, organisation across spatial levels provides a new understanding of the role of public space. For instance, organised communities in Asia facilitate remedial responses to multiple risks that their local environment poses such as poor living conditions, neglected public spaces and the threat posed by natural or climate-change related disasters. These communities are self-organised and rooted locally which aids in creating alliances and supporting recovery actions led by the local authorities: all of which serve to lessen the gravity of these challenges. Public space often provides the opportunity for prior organisation. These collective actions are simultaneously placebased and embedded in transnational networks such as 'Shack/Slum Dwellers International' (SDI) or the 'Asian Coalition for Housing Rights' (ACHR). This account does not aspire to justify a shift of responsibilities from the state to collective actors. Instead, it seeks to contribute to an emerging analytical framework on translocal social resilience.
\end{abstract}

Keywords: community resilience, translocal urbanism, placemaking, Asian Coalition for Housing Rights

To cite this article:

Ley, A. (2019), Community Resilience and Placemaking through Translocal Networking: Learning from Thailand and the Philippines. The Journal of Public Space, 4(2), I65-I78, DOI

10.3289|/jps.v4i2. 1208

This article has been double blind peer reviewed and accepted for publication in The Journal of Public Space.

This work is licensed under a Creative Commons Attribution - Non Commercial 4.0 International License https://creativecommons.org/licenses/by-nc/4.0/ 


\section{Introduction}

Research on community resilience has historically focused strongly on the local features of communities which are in support of and display resilient behaviour (e.g. Cutter et al, 2008; Chaskin, 2007). "Community adaptation" and "adaptive capacities" are some key words and concepts in this regard that take local self-organisation and assets into account. At the core of these concepts is the fact that social forms of resilience are cornerstones for realising resilient communities and averting concepts that were predominantly reliant on more technical systems or physical infrastructure. Similarly, the discourse surrounding public space has expanded into the non-physical notion of public space, whereby spatial enablement of social contact is seen to improve the quality of urban life.

The aim of this article is not to repeat the critique which relies on a narrow focus upon physical aspects or to foster the increased recognition of the significance of social and community resilience. Instead, the paper builds on this argument and identifies shortcomings in the discourse pertaining to community resilience and public space. Moreover, the aim of this paper is to extend the notion of place-based community resilience by highlighting that in today's world locality is characterised by "connectivity". This also has implications for the understanding of public space and placemaking beyond local territories: thereby positing the emerging concept of translocal social resilience in migration studies as an important point of reference (Sakdapolrak et al, 20l6). The underlying assumption is that communities which are organised on various levels are considerably more resilient than those that aren't as they are better equipped to cope with and adapt to the fallout resulting from a range of adverse situations and times of stress. Examples include but are not limited to natural disasters and hazards related to climate change. Moreover, networks of collective actors also present communities and individuals with the means to transform their livelihoods.

Translocal social networks and capacities can be found in migrant communities, but also in communities that have mobilised into networks beyond their locality, particularly around livelihood issues. Earlier studies on transnational urbanism (Smith 1998, Appadurai 1996, Krätke et al 2012) which include aspects of horizontal learning, peerto-peer support and mobilisation to collectively address injustice issues can collectively serve to inform the emerging concept of translocal social resilience. The paper will illustrate this with a case study on translocal and transnational community networks in Asia.

\section{Social Resilience through Community Networks}

Resilience has gained prominence as a concept that addresses the various complex challenges of urbanisation (Meerow et al, 2016; Wamsler, 20I4). Building resilience is a key aspect of global agendas such as the United Nations 2030 Agenda for Sustainable Development, and its Sustainable Development Goals (SDGs) and respective indicators that seek to measure "vulnerabilities" and "exposure" as well as the resilience capacity at a national level (Bahadur et al, 20I5). Furthermore, the Habitat III process and the resulting New Urban Agenda (NUA) seek to operationalise the resilience agenda at city level. A series of issue papers on urban resilience, subsequently published by the UN, underlined that cities need to be understood as complex and dynamically adaptive 
systems and that therefore the interconnected nature of risks and effects in urban areas needs to be acknowledged (UN-Habitat, 20I5).

However, the concept of resilience and the associated underlying definitions are rather vague and sometimes even partially contradictory. Some reduce it to post-disaster recovery (e.g. Campanella, 2016) while others view it as a comprehensive way to prepare for, mitigate and adapt to potential hazards (e.g. Bahadur et al, 20I5).

Furthermore, resilience is mostly associated with natural hazards and climate change. Even in the context of the Habitat III process urban resilience was limited to these aspects (see United Nations Task Team, 2015: 8). Other scholars suggest a broader understanding of underlying systems that need transformation in order to address inequality, vulnerabilities and the need to overcome barriers to develop adaptive capacities (Meerow et al, 2016: 46).

Unsurprisingly, the deriving actions depend on the underlying concept and as such are diverse. Nevertheless, disasters that have been occurring since the beginning of the 2 Ist century have led to an increase in awareness surrounding the significance of social resilience on an individual, household and community level (Sherrieb et al, 2010; Moser and Stein, 20I I; Walker and Salt, 20I2; Satterthwaite, 20I I). Social resilience is a people-centred concept which encompasses coping, adapting and the transformative capacities required to face the effects of a variety of shocks and times of stress (Keck and Sakdapolrak, 20I3; Mclan et al, 20I4; Saja et al, 2018). Community resilience can be considered part of this conceptual framework particularly in relation to the notion of capacities and resources of collective actors. As aforementioned, research surrounding community resilience has historically been markedly focused on the local features of communities which support and display resilient behaviour (e.g. Cutter et al, 2008; Berkes and Ross, 2012; Chaskin, 2007). Place-based actors in local communities are recognised as installing a proactive mode of climate governance. This view has gained particular momentum against the backdrop of a growing recognition of the implementation deficit at a national, as well as a municipal state level - accompanied by the reality that climate change is directly impacting local communities (vulnerability). State actors are seen to be lacking in the ability to frame the risks or enforce the necessary related actions (Kropp and Türk, 20I7).

Community resilience requires taking various factors into consideration that lie beyond mere physical attributes, such as social, economic or institutional conditions (Kwok et al, 2016). Some scholars argue that the concept of community resilience can be further informed by studying the adaptive capacities of informal settlement communities. The argument is that in this context there is a dynamic and continuous adaptation to changing conditions (Mendoza-Arroyo and Chelleri, 2017; Chaskin, 2007; Wilson, 20I4).

The concept of community resilience raises critical aspects in the context of informality where new tensions, forms of exclusion and resistance emerge and the framing of community is often blurred and contested (Mulligan et al, 2016). Community resilience needs to be critically reviewed against sometimes conflicting rationalities within communities and between communities and other scales of governance. The adaptation strategy adopted by an individual or one part of the community could thereby lead to increased overall vulnerability: also known as "maladaptation" (Burton, 1997). Mendoza-Arroyo and Chelleri (2017) therefore suggest applying the concept as defined 
by Mclean et al (20I4) who differentiate social resilience according to six attributes: (I) knowledge and skills, (2) community networks, (3) people's attachment to places, (4) community infrastructures, (5) diverse and innovative economies and (6) engaged governance. As one component of social resilience, community networks in particular looks in to relationship-building between individuals and communities. Similarly, but more comprehensively, Saja et al (2018) offer a social resilience framework based on previous frameworks. The inclusive framework outlines five dimensions (social structure, social capital, social mechanisms, social equity, and social belief) as well as corresponding characteristics and indicators.

\section{Public Space as Catalyst for Community Resilience}

The importance of place-based social networks in the context of climate change can be well illustrated by the 1995 Chicago heat wave during which the poor, African-American urban communities suffered the highest mortality rates. Surprisingly, a study conducted by Klinenberg (2002) showed that one of these poor communities in particular experienced comparably very low mortality rates, and thus proved to be an exception. The explanatory factor is that the public spaces present in the community, such as sidewalks and parks, played a significant role in enabling social contact between residents and thereby crucial support for vulnerable members of the community, the result of which was a reduction in the likelihood of heat-related deaths. Similarly, the significance of access to places that enable social contact could also be observed during Hurricane Sandy in New York City in 2012 and during Hurricane Katrina in New Orleans in 2005. Therefore, in her article "Resilience Is About Relationships, Not Just Infrastructure" Sarah Goodyear (2013) stressed: "As cities prepare for climate change in earnest, they're going to need to harden infrastructure, change building patterns, and overhaul government emergency procedures. But they're also going to have to put a greater value on the human connections that can be found in walkable neighbourhoods where people know each other and support local businesses."

Although public spaces seemingly play an important role in community resilience, the Charter of Public Space highlights the physical rather than the social dimension of public space with regards to mitigation and adaptation strategies to combat climate change. It specifically outlines a) its role in regulating environmental change (e.g. microclimates in public spaces), for increased environmental protection (e.g. of river banks) and the lowering of environmental risks, and b) the need to use public spaces for rebuilding initiatives in the wake of disaster events (UN-Habitat 2016: 129). Consequently, placebased approaches to community resilience are often related to the local techno-physical conditions of public space. The function of public space as a place which encourages social-contact receives more recognition when it comes to addressing urban development challenges in general.

Klaus Selle (PT, 2017) and Carmona et al (2003) define spaces for social interaction that enable incidental social contact as "public useable space". This definition can also entail privately-owned spaces that are open for public use and accessible in principle (however not always in practice). In the context of informal settlements, the idea that public space provides a "living room" that allows for social interaction, and encourages identification and feelings of belonging - along with the associated social and economic benefits for 
vulnerable communities in dense living environments - has been particularly emphasised (UN-Habitat, 2016: vii). This understanding resonates with the conceptualisation of community resilience. Consequently, "placemaking" can be understood as a community resilience effort, as both processes indicate collaborative action in the public realm with the aim of strengthening social ties beyond physical infrastructure and the confines of urban design. Related public space-led approaches to "slum upgrading" take their starting point in public space, often in streets, when it comes to organising communities. While participation around issues such as housing is rather complex and conflict-laden, "citizens mobilize over a public space they want to create or maintain" (UN-Habitat, 2016: 21). Thus, in dense environments, public space is seen as a catalyst for upgrading, in addition to civic engagement.

\section{Translocal Connectivity Promotes Community Resilience}

According to both Mclean et al (20l4) and Saja et al (20l8), community networks are one of the key attributes of social resilience. Studies indicate that a) well-organised communities are better prepared for both the occurrence of disaster events and their aftermath (UN, 20I4; Rahman and Kausel, 2013) and b) community relationship-building is positively influenced by the existence of public space that allows for social contact. The importance of existing local networks is by now recognised in the scientific literature (Twigg and Mosel, 20 I8; Satterthwaite, 20I I). What has been less included in studies on community and social resilience, and public space and placemaking, is the critical role of that connectivity plays beyond localities. For instance, the inclusive social resilience framework drawn up by Saja et al (2018) details a set of characteristics that focus on social cohesion, social support and social networks under the sub-dimension 'social capital'. Under 'social networks', three indicators which measure the resilience of social networks to disasters are provided, they are: civic engagement, civic organisations and volunteerism (Saja et al 2018: 868). None of these indicators pay particular attention to initiatives beyond locality.

Similarly, definitions of public space often encompass both physical and non-physical characteristics. Both characteristics are rather following a particular understanding of public space in terms of locality and "community of place" (Gerson et al, 1977). Among the non-physical characteristics, particular mention is made only of cyberspace: "Cyberspace, through the internet and social networks, offers new opportunities for virtual encounter and interaction that can lead to the multiplication of 'real' interactions in 'real' space" (UN-Habitat, 2016: 28). This notion can however be contested, as scholars caution that the expansion of social media and digitalisation might also contribute to further social polarisation and exclusion, and instead highlight the need for offline activities for social relations (Harari, 2018). Also missing, is the acknowledgement that public space needs to be understood as a physical phenomenon which is influenced by initiatives, skills and knowledge from across and beyond local territories which are not limited to cyberspace. This will be instrumental in the future when it comes to framing public spaces as loci for encounters, interaction and communication.

The notion that social networks operate beyond the place-based community needs to be taken into consideration for conceptualising community resilience and placemaking. In the aftermath of Hurricane Katrina in New Orleans, it was the Vietnamese-American 
community that recovered more quickly, in spite of the fact that it was one of the poorest in the city. Instead of drawing on government resources, this community relied on a globally organised diaspora to financially support the recovery and rebuilding processes (Leong et al, 2007). However, communities that had to recover without this kind of network-based financial support - such as the African-American communities were badly affected. The message here is not to downplay the importance of state intervention, but instead to contribute to an understanding of the key role that relationship-building plays in community resilience, beyond the physical boundaries of localities.

This realisation corresponds to findings in the field of transnational urbanism which highlight that cities are sites of transnational practices both, "from above" (through transnational corporations, global production chains and elites) and "from below" (Smith, 1998). "Transnationalism from below" (Miraftab, 2009) is often studied in terms of how migrants establish transnational links and thereby create "translocalities". The original methodological approach to the area of study was mostly limited to ethnography and to the individual citizen (migrants, creative class) in the city, as the object of study. Migration studies have pushed the envelope on connectedness by framing the links between migrants and their place of origin (e.g. Levitt and Glick Schiller 2004). This debate recently also referred to migration in the face of climate change (migration as adaptation). One critique in the scholarly debate on migration as adaptation is that these studies "tend to take networks for granted, rather than focusing on the way networks evolve over time" (Sakdapolrak et al 2016: 86). Sakdapolrak et al (2016) posit translocal social resilience as an analytical framework that includes: a) social practices, b) the social constructedness of migration-environment links, and c) connectedness of actors and places. The latter aspect highlights that networks are the basis and outcome of practices that relate to communication and the exchange of resources and ideas. The concept thereby emphasises the role of social actors as embedded in translocal networks, however, without particularly shedding light on the role of collective actors and public spaces as a catalyst for the appearance of translocal connectedness in the first place.

A different kind of attention has recently been paid to organised, place-based collective civil society actors, their cross-boundary networks and their respective methods for improved mobility of resources. Here, the civil society discourse - in particular the scholarly debate around urban social movements - goes beyond the individual and takes the importance of the globalising context into account in relation to organised actors. What is indicated here is a trajectory from a micro-level activity to macro-level activism (Gaventa and Tandon, 2010; Sassen, 2004).

Practices that take place in civil society and within networks are often locally rooted, but at the same time they also form part of translocal and transnational exchange processes. Transnational networks of urban poor have hardly been focused upon in respect of improving living conditions. The activities promoted by Shack/Slum Dwellers International (SDI) and the Asian Coalition for Housing Rights (ACHR) are illustrative examples as both organisations represent transnational alliances between local federations and support Non-Governmental Organizations (NGOs). Their underlying local-global practices include collective processes of mappings and enumerations in informal settlements involving peers from other countries, group savings that not only 
allow for local loan distribution, but scale up to national and international funds as well as exchanges of federation members across space to support and learn from one another. All these strategies are meant to strengthen interaction amongst individual members and federations as well as to secure relations to the state and international agencies. In particular, the approach adopted by the ACHR takes examples of public space upgrading, such as the cleaning of river banks in informal settlement communities, as a starting point for organising local communities which allows for a more comprehensive form of upgrading to emerge.

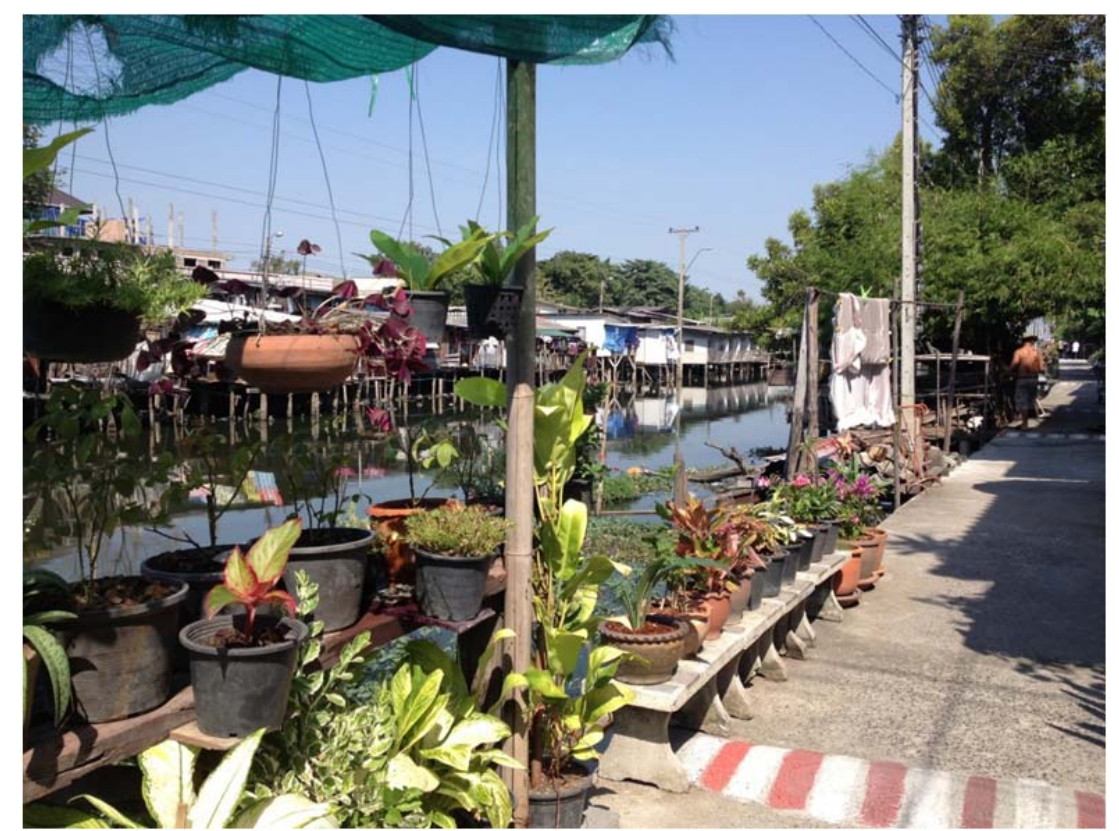

Fig. I. An upgraded river bank in the Ban Bua channel community, Bangkok, Thailand. Source: Ley, 2013.

The locally rooted and internationally networked processes such as the river upgrading in Bangkok highlight two important aspects for community resilience and placemaking: firstly, urban poor networks with a translocal and transnational scope can leverage critical negotiation power and thereby receive recognition as partners in urban development and secondly, the re-adjustment of the interface between government and civil society can lead to more collaborative forms of urban governance (Herrle et al, 2015). To what extent are these new actor constellations of importance when it comes to resilience, for example in the case of natural hazards and the emergence of risks related to climate change?

\section{Learning from Thailand and The Philippines}

Organised communities in Asia are accustomed to facilitating responses to multiple risks and vulnerabilities. They create alliances and support recovery actions led by the local authorities, and overcome hazards and disasters. Well-organised community networks are therefore increasingly involved in recovery processes in the wake of disasters. 
These collective actions are embedded in transnational networks such as SDI or the ACHR. A cornerstone of this recovery philosophy is the framing of communities as "agents for change" and not relief-dependent victims; in addition to embedding the understanding that rebuilding ought to be centred around residents' livelihoods and not merely around the rebuilding of physical shelters (Archer and Boonyabancha, 20I I).

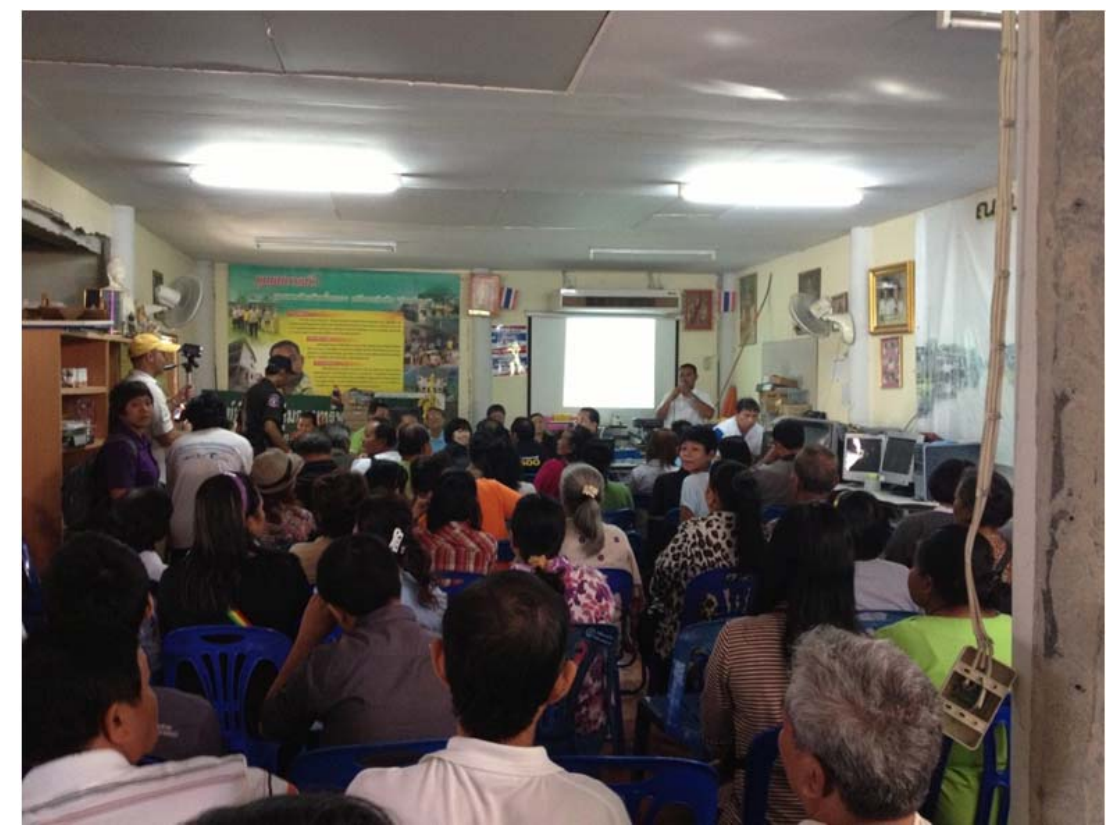

Fig. 2. Community meeting with ACHR members in attendance, Bangkok, Thailand. Source: Fokdal 2013.

The 2004 Indian Ocean tsunami hit around 3300 settlements along the coast of South and Southeast Asia, killing 350.000 people and leaving another 2.5 million homeless. Furthermore, conventional disaster relief efforts were characterised by a lack of coordination and a top-down approach that undermined people's initiative. Against this background, the ACHR attempted to strengthen the collective capacities of affected communities for the purposes of disaster rehabilitation, and beyond.

In Thailand for instance, communities that were affected by the aforementioned tsunami linked their activities and exchanged their experience around how each of them has managed the rehabilitation process. Through face-to-face meetings, innovative ideas or solutions could be transferred rapidly. Each province has now set up a network of tsunami-affected communities, to support one another in negotiating with the state and managing their own funds.

One important aspect of their preparedness was that many of these communities had already organised themselves for such an event, prior to the disaster (personal communication Celine D'Cruz, ACHR, April 2017). The Community Planning Network in Southern Thailand for instance had already established horizontal learning between communities as a mode of operation. After the tsunami, they supported relief operations as well as negotiations in opposition to evictions. Some of these networks were born out of specific issues. One of these issue-based networks is the boat-building 
network, which helps to ensure that communities don't have to wait for government compensation but are provided with immediate and flexible mutual support in negotiations and the boat-building skills necessary in order to begin restoring livelihoods. On a more strategic level, communities facing evictions joined forces to resolve land conflicts.

Collective management is also exercised in regards to pooling financial resources. In conventional disaster relief processes, households compete individually against one another for scarce resources. In the Philippines, the Homeless People's Federation (HPFP) engaged existing saving groups or initiated new saving programs to secure the down payments of loans and to top up donor finances (Archer and Boonyabancha, $20 \mathrm{II}$ ). This is not only of importance with regards to disasters, indeed almost half of the urban population resides in informal settlements which have scarce access to basic infrastructure and are characterised by insecure tenure. In response to these conditions, the HPFP strives to unite these communities across the country, to address these deficiencies.

In the wake of the 2009 Typhoon Ketsana, the federation issued house repair loans at the community level, thereby initiating a collective process in terms of construction management. Moreover, the collective nature of the process facilitated a rapid loan repayment, hence the original amount of 20.000 USD could be loaned three times and support households across the country in the worst affected urban areas of Quezon City, Muntinlupa and Bulacan (ACHR, 20I4).

This is not to say that communities' capacities and collective activities are somehow substituting the role of the state. But these communal efforts do form part of a larger framework that brings both top-down and bottom-up initiatives and capacities together. City level forums are such platforms for mutual learning on the theme of collaboration and it is in this way that organised communities need to build on their capacity to engage with local governments. One such approach to finding alternative solutions during negotiations is to use instruments such as data collection in informal settlements, and information that is not available to local government urban planners.

Another approach is to use housing exhibitions that showcase the use of sustainable materials, local labour and safe building techniques to decision-makers. For instance, after Typhoon Frank hit the Philippines in June 2008 which flooded $80 \%$ of the City of Iloilo and affected 53.000 families (HPFP, 2009), the Homeless People's Federation Philippines (HPFP) identified a relocation site in San Isidro to showcase an alternative rebuilding approach.

One scale-up tactic of these alternative approaches is to invite political decision-makers along on exposure trips. For instance, the mayor of Camalig - a municipality where federation groups were relocated after the 2008 typhoon - was taken to the City of Iloilo for a peer-to-peer exchange with the city's mayor, to learn about the process of bringing federation and city council together for a city-wide strategy (d'Cruz, 2009). These kinds of community-led responses are communicated on a translocal scale through exposure visits, peer-to-peer exchanges and publications. Forms of horizontal learning facilitate a people-centred resilience process whereby connected communities consult one another and jointly stand against the implications of top-down planning. For instance, many communities faced the threat of evictions after the 2004 Asian tsunami when governments, such as Thailand, introduced coastal regulation zones and thereby 
hindered the affected communities' efforts to return. Networking opened the door for displaced communities that resided on coastal land to negotiate government land rights issues (ACHR, 2006).

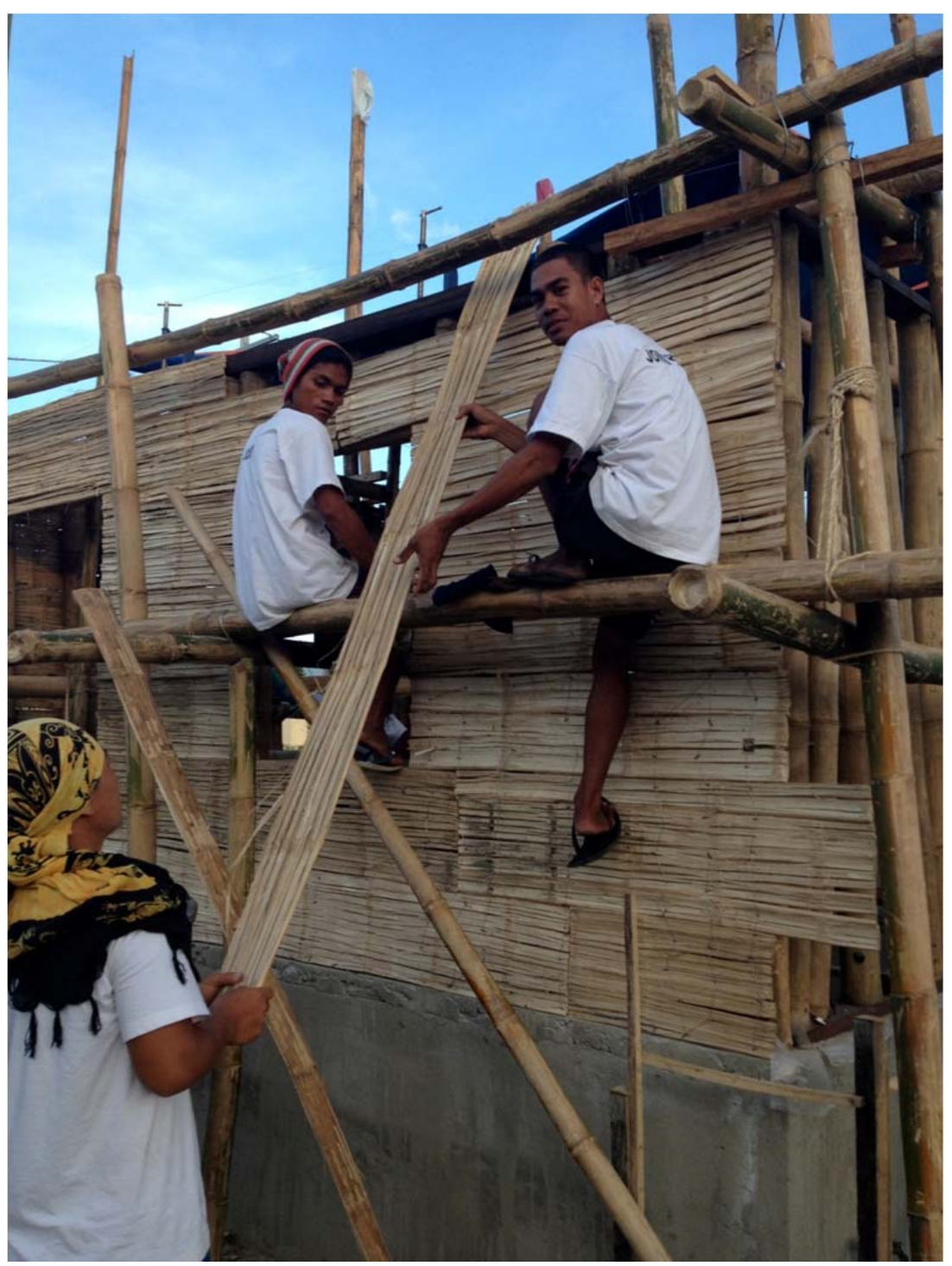

Fig. 3. Housing exhibition at the San Isidro relocation site, Iloilo City, the Philippines. Source: Fokdal 2013.

Translocal connectivities are, however, not free of critique. The capacity of the urban poor to organise transnationally is disputed. Rather, transnational activities are considered to be of further burden on these already vulnerable groups (Pithouse, 20I2). The implementation of such relationship-building beyond the locality only makes sense for communities if it is of relevance to the local context. In the context of the ACHR it is seen as a complementary strategy for otherwise place-based communities whose trust and opportunity for knowledge production and engagement with the state is based on proximity. 
Smaller geographies and constituencies support the principle that relationships matter, makes it possible to engage qualitatively with the nature of power, keeps the knowledge produced relevant to engage with the local politics and allows communities to go at their pace. I am learning that going global is not necessarily all good and actually jeopardizes the principles besides being more expensive. Global makes sense as long as it is deeply relevant to the local.

(personal communication with Celine d'Cruz, May 2018)

\section{Conclusion}

Prior organisation within individual communities and establishing connectivity beyond singular localities - sometimes on a national or even international level - need to be taken into consideration as significant aspects of community resilience and placemaking. Prior organisation is of significance because this is an important precondition for ensuring capacities for resilience before, during and after a crisis. Public space can be seen here as a catalyst for social interaction and joint activities. It facilitates community mobilisation and organisation before entering more complex community upgrading. Also of significance is the issue of connectivity between collective actors. The focus here is on translocal and transnational networks of urban poor, particularly around improving their livelihoods and in addition, settlements in Asia that mobilise members (often around the issue of public space upgrading), generate knowledge and facilitate the mobility of knowledge through a re-scaling of their established practices. This localglobal activism is a new phenomenon which offers some initial indications as to its potential to influence community resilience in particular, and public space more generally.

The translocal community networks in Thailand and the Philippines have shifted their focus from individual households to collective management strategies as a long-term solution. This also illustrates how communities are networking beyond the scope of rebuilding physical shelters and instead seeking a posits their livelihoods as the main focal point. Moreover, this translocal peer-to-peer support system seems to address some critical issues such as giving a stronger voice to disaster affected communities to express their needs to other actors.

Nevertheless, two challenges must be considered. Firstly, as with any community process and related discourses around social capital there needs to be a critical assessment as to whether or not these activities ultimately lead to the exclusion of groups who are outside the networks (Twigg and Mosel 2018: 12). This also applied to translocal community resilience and placemaking. Secondly, community-led processes with a focus on translocal network-building need to build on capacities and investments in terms of time to mobilise and establish relationships. However, this often overburdens already vulnerable communities and stands in stark contrast to the rapid response agenda favoured by many donors in post-disaster situations (Archer and Boonyabancha, 20II).

In addition to community resilience and placemaking, translocal activities need to be considered as a complementary strategy capable of creating synergies, to the responsibilities and efforts of other actors for achieving a state of overall resilience in 
cities, and be further acknowledged in global policy related to public space. Until now, translocal activities have been overlooked in favour of pro-active community involvement and the ability to be resilient in public spaces.

\section{Acknowledgment}

The article draws on findings of research conducted with a focus on transnational connections of urban poor (Herrle et al 20I5) and an expert group workshop on "Collective action and resilience in emerging city regions" organised at the University of Stuttgart in April 2017. A shorter and earlier version was published as a conference proceeding - see: Ley, A.: Translocal networking as a cornerstone for community resilience: Activities by the Asian Coalition of Housing Rights (ACHR), International Forum on Urbanism Conference "Reframing Urban Resilience Implementation", Barcelona, December 2018, https://sciforum.net/manuscripts/5996/manuscript.pdf (accessed 09. August 2019). I would like to thank Celine d'Cruz from the Asian Coalition for Housing Rights and losefine Fokdal from the University of Stuttgart for their constructive comments concerning early versions of the manuscript.

\section{References}

Appadurai, A. (1996). Modernity at large: cultural dimensions of globalization, Minneapolis: Minnesota Press.

Archer, D. and Boonyabancha, S. (20I I). 'Seeing a disaster as an opportunity- harnessing the energy of disaster survivors for change', Environment and Urbanization, 23(2), 35I-364.

Asian Coalition for Housing Rights (ACHR) (2014). 'Homeless People's Federation Philippines in 15 cities and 6 disaster-hit areas', in Cities in Asia, Fifth Yearly Report of the Asian Coalition for Community Action Program, 215, 4I.

Asian Coalition for Housing Rights (ACHR) (2006). 'The Power of People's Networks: Vulnerable communities find that linking together in different ways allows them to do all kinds of things they could never do in isolation', Tsunami Update, 5, available: http://www.achr.net/upload/downloads/file 2212201302160I.pdf [accessed 29 Sept 2019].

Bahadur, A., Lovell, E., Wilkinson, E., Tanner, T. (20I5). 'Resilience in the SDGs: Developing an indicator for Target I.5 that is fit for purpose', ODI briefing papers, August 2015, available: https://www.odi.org/sites/odi.org.uk/files/odi-assets/publications-opinion-files/9780.pdf [accessed 29 Sept 2019].

Berkes, F., Ross, H., (2012). 'Community Resilience: Toward an Integrated Approach', Society \& Natural Resources, 26(I), 5-20.

Burton, I. (1997). 'Vulnerability and adaptive response in the context of climate and climate change', Climatic Change, 36(I-2), I85-196.

Campanella, T.J. (2006). 'Urban resilience and the recovery of New Orleans', Journal of the American Planning Association, 72(2), I4I-I46.

Carmona, M., Heat, T., Oc, T. and Tiesdell, S. (2003). Public Places, Urban Spaces: The Dimensions of Urban Design, London: Architectural Press.

Chaskin, R. J. (2007). 'Resilience, Community, and Resilient Communities: Conditioning Contexts and Collective Action', Child Care in Practice, I4(I), 65-74.

Cutter, S. L., Barnes, L., Berry, M., Burton, C., Evans, E., Tate, E. and Webb, J. (2008). 'A placebased model for understanding community resilience to natural disasters', Global Environmental Change, 18, 598-606. 
d'Cruz, C. (2009). 'Leadership in urban areas', Tiempo, 72, p. 3-8. Download:

http://www.citiesalliance.org/ca/sites/citiesalliance.org/files/CA_Images/Tiempo_CelinedCr uz_July09.pdf [accessed 0I. July 2018].

Gaventa, J. and Tandon, R. (eds.) (20I0). Globalizing Citizens: New Dynamics of Inclusion and Exclusion, London: Zed Books.

Gerson, K., Stueve, A. and Fischer, C.S. (1977). 'Attachment to Place', In Fischer, C.S. et al (eds.), Networks and Places: Social Relations in the Urban Setting, New York: The Free Press.

Goodyear, S. (2013) 'Resilience Is About Relationships, Not Just Infrastructure', https://www.citylab.com/environment/2013/01/resilience-about-relationships-not-justinfrastructure/4305/ (accessed 22 August 2019).

Harari, Y. N. (20I8). 2 I Lessons for the 2 Ist Century, London: Jonathan Cape.

Herrle, P., Ley, A. and Fokdal, J. (eds.) (2015). From Local Action to Global Networks: Housing the Urban Poor, London: Ashgate.

Homeless People's Federation Philippines (HPFP) Thinking City-Wide in Iloilo City, Philippines, Blog http://homelessiloilo.blogspot.com [accessed 06 August 2018].

Keck, M. and Sakdapolrak, P. (2013). 'What is social resilience? Lessons learned and ways forward', Erdkunde, 67 (I), 5-19.

Klinenberg, E. (2002). Heat wave: a social autopsy of disaster in Chicago, Chicago: Chicago Press.

Krätke, S., Wildner, K. and Lanz, S. (eds.) (20I2). Transnationalism and Urbanism, Routledge Research in Transnationalism, 25, Routledge: London and New York.

Kropp C., Türk J. (20I7). 'Bringing Climate Change Down to Earth: Climate Change Governance from the Bottom Up', In Esguerra, A., Helmerich, N. and Risse T. (eds.) Sustainability Politics and Limited Statehood. Governance and Limited Statehood, Cham: Palgrave Macmillan, 179-2I0.

Kwok, A.H., Doyle, E.E.H., Becker, J., Johnston, D. and Paton, D. (2016). 'What is "social resilience"? Perspectives of disaster researchers, emergency management practitioners, and policy makers in New Zealand', International Journal of Disaster Risk Reduction, 19, 197211 .

Leong, K. J., Airriess, C.A., Li, W., Chia-Chen Chen, A. and Keith, V.M. (2007). 'Resilient History and the Rebuilding of a Community: The Vietnamese American Community in New Orleans East', in The Journal of American History, 94 (3), 770-779.

Maclean, K., Cuthill, M., and Ross, H. (2014). 'Six attributes of social resilience', Journal of Environmental Planning and Management, 57(I), I44- 156.

Meerow, S., Newell, J.P. and Stults, M. (2016). 'Defining Urban Resilience: A review', in Landscape and Urban Planning, I47, 38-49.

Mendoza-Arroyo, C. and Chelleri, L. (2017). 'The Potential of Community Resilience in Unveiling Social-Economic Dynamics for Informal Settlement Up-Grading', in: Tieben, H., Geng, Y. and Rossini, F. (eds.) The Entrepreneurial City, IOth conference of the International Forum on Urbanism (IFoU), Rotterdam: International Forum on Urbanism (IFoU), 169-180.

Miraftab F. (2009). 'Insurgent Planning: Situating Radical Planning in the Global South', Planning Theory, 8 (I), 32-50.

Moser, C. and Stein, A. (201 I). 'Implementing urban participatory climate change adaptation appraisals: a methodological guideline', Environment and Urbanization, 23(2), 463-485.

Mulligan, M., Steele, W., Rickards, L., and Funfgeld, H. (2016). 'Keywords in planning: what do we mean by 'community resilience'?' International Planning Studies, 2 I (4), 348-36I.

Pithouse, R. (2012). 'Move from and not on the Occult Zone (Where the People Dwell): An Argument for the Political Priority of Solidarity with Popular (and Largely Situated) Mobilization by the Poor over Transnational Organization by Civil Society', in: Krätke, S., 
Wildner, K. and Lanz, S. (eds.) Transnationalism and Urbanism, Routledge Research in Transnationalism, 25, Routledge: London and New York, 197-223.

PT - Lehrstuhl für Planungstheorie und Stadtentwicklung RWTH Aachen University (2017). 'Öffentliche Räume in stadtgesellschaftlich vielfältigen Quartieren: Nutzung, Wahrnehmung und Bedeutung', PT Materialien No. 37.

Rahman, Md. S. and Kausel, T. (2013). 'Coastal Community Resilience to Tsunami: A Study on Planning Capacity and Social Capacity, Dichato, Chile', IOSR Journal Of Humanities And Social Science, I2 (6), 55-63.

Saja, A. A.M., Teo, M., Goonetilleke, A. and Ziyath, A.M. (2018). 'An inclusive and adaptive framework for measuring social resilience to disasters', International Journal of Disaster Risk Reduction, 28, 862-873.

Sassen, S. (2004). 'Local Actors in Global Politics', Current Sociology, 52(4): 649-670.

Satterthwaite, D. (20II). 'Editorial: Why is community action needed for disaster risk reduction and climate change adaptation?', Environment and Urbanization, 23(2): 339-349.

Sherrieb, K., Norris, F. H. and Galea, S. (2010). 'Measuring Capacities for Community Resilience', Social Indicators Research, 99(2), 227-247.

Smith, M.P. (1998). Transnational Urbanism. Locating Globalization, Blackwell: Malden.

Twigg, J. and Mosel, I. (20I8). 'Informality in urban crisis response', ODI working paper, 532, March 2018, available: https://www.odi.org/sites/odi.org.uk/files/resourcedocuments/I2065.pdf [accessed 29 Sept 2019].

UN-Habitat (2016). 'Global Public Space Toolkit: From Global Principles to Local Policies and Practice', Nairobi, Revision February 2016, available: https://unhabitat.org/wpcontent/uploads/2015/I0/Global\%20Public\%20Space\%20Toolkit.pdf [accessed 29 Sept 2019].

United Nations (UN) (20I4). 'Pro-poor urban climate resilience in Asia and the pacific, Nairobi, available: http://www.unescap.org/sites/default/files/Quick\%20Guide\%20for\%20Policy\%20Makers.pdf [accessed 06 April 2018].

United Nations Task Team (20I5). 'Habitat III Issue Papers. HABITAT III ISSUE PAPERS. I5 Urban Resilience, New York, 3I May 20I5, available: http://habitat3.org/wpcontent/uploads/Habitat-III-Issue-Paper-15_Urban-Resilience-2.0.pdf [accessed 06 April 20l8].

Walker, B. and Salt, D. (2012). Resilience Practice: Building Capacity to Absorb Disturbance and Maintain Function, Island Press: Washington D.C.

Wamsler, C. (20I4). Cities, Disaster Risk and Adaptation, Routledge: London.

Wilson, G. A. (20I4). 'Community resilience: path dependency, lock-in effects and transitional ruptures', Journal of Environmental Planning and Management, 57(I), I-26. 